OPEN ACCESS

Edited by:

Ali Serhan Tarkan, Muğla Sıtkı Koçman University, Turkey

Reviewed by:

Ertan Ercan,

Muğla Sıtkı Koçman University, Turkey

Lyubov Burlakova,

Buffalo State College, United States

${ }^{*}$ Correspondence:

Carlos Garcia de Leaniz

c.garciadeleaniz@swansea.ac.uk

Specialty section:

This article was submitted to

Conservation,

a section of the journal

Frontiers in Ecology and Evolution

Received: 13 March 2020

Accepted: 07 May 2020

Published: 09 June 2020

Citation:

Rolla M, Consuegra S, Hall DJ and Garcia de Leaniz C (2020)

Seasonal and Spatial Variation

in Growth and Abundance of Zebra

Mussel (Dreissena polymorpha) in a

Recently Invaded Artificial Lake:

Implications for Management.

Front. Ecol. Evol. 8:159.

doi: 10.3389/fevo.2020.00159

\section{Seasonal and Spatial Variation in Growth and Abundance of Zebra Mussel (Dreissena polymorpha) in a Recently Invaded Artificial Lake: Implications for Management}

\author{
Matteo Rolla ${ }^{1}$, Sofia Consuegra ${ }^{1}$, David J. Hall ${ }^{2}$ and Carlos Garcia de Leaniz ${ }^{1 *}$ \\ 1 Department of BioSciences, Centre for Sustainable Aquatic Research, Swansea University, Swansea, United Kingdom, \\ ${ }^{2}$ Cardiff Harbour Authority, Queen Alexandra's House, Cardiff, United Kingdom
}

The control of the highly invasive zebra mussel (Dreissena polymorpha) has been flagged as a priority but success has been variable. A better understanding of the growth and drivers of settlement of zebra mussel is necessary for a more efficient management of this invasive species, but seasonal data are still relatively scant. We monitored the seasonal changes in settlement rates, density, and growth of zebra mussel in artificial substrates over 1 year in Cardiff Bay (United Kingdom), an artificial amenity lake invaded by zebra mussels in 2004, where the species is rapidly expanding. Mean settlement rates varied from 4,200 to 6,200 mussel $\mathrm{m}^{-2}$ over June to September mirroring changes in water temperature, and peaked at 17,960 mussels $\mathrm{m}^{-2}$, the highest density reported in Britain. Density was highest at the deepest panels $(3 \mathrm{~m})$. Growth varied significantly among sampling stations, taking place during the summer and ceasing during winter and spring. Mixture analysis reveals the existence of multiple cohorts displaying different growth and settlement rates that follow different density dependent mechanisms, being positive density-dependent at low densities, and negative densitydependent at high densities. We suggest this creates the conditions necessary for source and sink metapopulations to develop which may need to be considered in management. Targeting mussels for removal in deep waters during the summer and early autumn might prove beneficial, but the existence of contrasting density-dependent mechanisms suggests that removal may be beneficial or counterproductive depending on local conditions. Keywords: aquatic invasive species, population dynamics, density-dependence, colonization, bivalves (mussels),
growth

\section{INTRODUCTION}

The zebra mussel (Dreissena polymorpha) is one of the most damaging aquatic invaders (Strayer, 2010), having been included in the list of the 100 world's worst alien species (Lowe et al., 2000). Zebra mussels can drastically reduce the biomass of phytoplankton, and change its community composition, which can in turn change water parameters, resuspend nutrients into the water 
column (Bastviken et al., 1998), and increase water transparency (Holland, 1993; Fahnenstiel et al., 1995). The species can compete for food and space with native freshwater mussels and drive them to extinction through epizootic colonization, disruption of their valve functionality, smothering of their siphons, and impairing of their movement through deposition of metabolic waste (Schloesser et al., 1996; Baker and Hornbach, 1997). A strong association has been found between density of zebra mussels and mortality of native unionid mussels (Ricciardi et al., 1995).

The economic losses caused by zebra mussels can be considerable. They can block pipes and water supplies, intakes from nuclear, hydroelectric and industrial facilities (O'Neill, 1997), and clog the cooling systems of power boats (Johnson et al., 2001). Navigation buoys have been sunk under the weight of zebra mussels, and dock pilings can become severely weakened due to zebra mussel encrustations (Minchin and Moriarty, 1998). In the United States, the cost of cleaning a single hydroelectric plant of zebra mussels may amount to $\$ 92,000$ per year, and the combined costs may have reached $\$ 6.5$ billion over 10 years (Lovell et al., 2006). Not surprisingly, the control of zebra mussel has become a priority (Aldridge et al., 2004, 2006; Strayer, 2010). However, eradication measures are seldom successful (Whitledge et al., 2015; Lund et al., 2018), may require repeated treatments, and may have to be extended over several years (Table 1). The only known completely successful eradication program was reported in Millbrook Quarry (United States) using $12 \%$ potassium (Fernald and Watson, 2013). In Lake George (United States), manual SCUBA diving removal during eight consecutive years eradicated zebra mussel from a private marina, but new small colonies appeared in other parts of the lake that required further control (Wimbush et al., 2009). OAFB (2009) reported the successful eradication of zebra mussel in lake Offutt (United States) using copper sulfate, however, in 2014 the species was found again in the lake (Britton, 2015). A local eradication program in the Grand Canal (Ireland) using the molluscicide Zequanox failed to remove zebra mussel (Meehan et al., 2014). Similar failures have been reported in Deep Quarry (United States) (Whitledge et al., 2015) and in Christmas Lake (United States); in the last case the local eradication was successful, but zebra mussel were subsequently found outside the treated area (Lund et al., 2018).

Some traits of the zebra mussel make their eradication particularly challenging: (1) the species is highly fecund (up to 1 million eggs per female), (2) has a planktonic veliger stage which can travel over great distances and survive for weeks (Minchin et al., 2002), (3) displays high tolerance to a wide range of temperatures $\left(-10.3\right.$ to $28.0^{\circ} \mathrm{C}$; Spidle et al., 1995; Gallardo et al., 2013), salinities (0-18.4\% ; Kilgour et al., 1994; Karatayev et al., 1998; Orlova et al., 1998) and $\mathrm{pH}$ values (6.5-11.1; Claudi and Mackie, 1993; Bowman and Bailey, 1998; Bodamer and Bossenbroek, 2008), and (4) has a tendency to aggregate in enormous beds (up to 32,500 individuals $/ \mathrm{m}^{2}$, Berkman et al., 1998) on different types of substrates. Zebra mussel invasions have been facilitated by many anthropogenic actions, including the building of canals and channels that connect formerly isolated water bodies (Decksbach, 1935), boat trading (Kearney and Morton, 1970) and aquatic leisure activities (Kinzelbach, 1992).
These can make eradication particularly difficult, as the risk of recolonization from connected water ways is always high (Mari et al., 2011). In Britain, the first record of zebra mussel dates back to 1824 , but it is only since 2000 that the species has started to spread rapidly and cause widespread ecological damage, a pattern that cannot be explained simply by increasing public awareness (Aldridge et al., 2004) and that remains unclear.

One pressing issue with the control of zebra mussel is to assess to what extent incomplete eradication (i.e., partial removal) is useful in controlling population growth and limit dispersal, or on the contrary, may cause more harm than good if populations simply bounce back in greater numbers. Under controlled environments, mitigation measures can help reduce the abundance of zebra mussel (Luoma et al., 2018; Waller and Bartsch, 2018), which could help reduce impacts (Wimbush et al., 2009; Fernald and Watson, 2013). However, information on natural systems is very scant and models have typically low predictive power to predict zebra mussel dispersal patterns (Rodríguez-Rey et al., 2019). The ability of zebra mussel to recover from partial removal will likely depend on seasonal patterns of growth and recruitment, which have been correlated with seasonal temperatures (Allen et al., 1999), and chlorophyll-a (Churchill et al., 2017), but also with calcium, alkalinity, and total hardness (Hincks and Mackie, 1997). Mortality and recruitment appear to be influenced by fluctuations in temperature, but also by population size structure (Allen et al., 1999), and there is some evidence that settlement of new juveniles is negatively affected by the density of established adult mussels (Nalepa et al., 1995), suggesting the existence of negative densitydependence processes.

The recruitment and demography of zebra mussel have been well studied in North America (Martel, 1993; Nalepa et al., 1993; Martel et al., 1994; Chase and Bailey, 1999) but there is relatively little information on the dynamics of the species in recently invaded waters in Europe (MacNeil et al., 2010; Alix et al., 2016). Nor is it clear how populations are structured during the initial stages of the invasion, when boom and bust dynamics might be expected (Strayer et al., 2017), and where a better understanding of growth and recruitment could make control measures more efficient.

We monitored the colonization and growth of zebra mussel in experimental panels submerged at different depths in Cardiff Bay (Wales, United Kingdom), an amenity lake where the species is spreading and causing increasing damage. Zebra mussels were first recorded in Cardiff Bay in 2004 (although they may have been introduced a year earlier), and have spread rapidly since, being now present throughout the Bay (Alix, 2010; Wood et al., 2015; Alix et al., 2016).

Zebra mussels cause a major management issue in Cardiff Bay. To comply with dissolved oxygen standards contained within the Cardiff Bay Barrage Act, an aeration system consisting of $26 \mathrm{~km}$ of pipework pumps compressed air into the lake to ensure oxygenated water is mixed through the water column and anoxic water pockets are not formed. The aeration system is colonized by zebra mussels which clog the diffusers and reduce oxygenation, requiring regular cleaning. Zebra mussel also foul many boats found in the area, as well as two fish passes constructed within 
TABLE 1 | Examples of eradication programs of zebra mussel.

\begin{tabular}{|c|c|c|c|c|c|c|c|}
\hline Site & Type & Method & Time after first record & Duration & Cost & Success & References \\
\hline $\begin{array}{l}\text { Lake George } \\
\text { United States }\end{array}$ & $\begin{array}{l}\text { Localized } \\
\text { eradication }\end{array}$ & $\begin{array}{l}\text { Mechanical removal } \\
\text { SCUBA divers }\end{array}$ & Few months & 8 years & NA & Y & Wimbush et al., 2009 \\
\hline $\begin{array}{l}\text { Lake Offutt } \\
\text { United States }\end{array}$ & $\begin{array}{l}\text { Whole site } \\
\text { eradication }\end{array}$ & Copper Sulfate & 2 years & 4 days & NA & Y & OAFB, 2009 \\
\hline $\begin{array}{l}\text { Millbrook Quarry } \\
\text { United States }\end{array}$ & $\begin{array}{l}\text { Whole site } \\
\text { eradication }\end{array}$ & $12 \%$ Potassium & 4 years & 3 weeks & $\$ 800,000$ & Y & Fernald and Watson, 2013 \\
\hline Grand Canal Ireland & $\begin{array}{l}\text { Localized } \\
\text { eradication }\end{array}$ & Zequanox & NA & 1 treatment & NA & $\mathrm{N}$ & Meehan et al., 2014 \\
\hline $\begin{array}{l}\text { Deep Quarry } \\
\text { United States }\end{array}$ & $\begin{array}{l}\text { Localized } \\
\text { eradication }\end{array}$ & Zequanox & 3 year & 2 treatments & NA & $\mathrm{N}$ & Whitledge et al., 2015 \\
\hline $\begin{array}{l}\text { Christmas Lake } \\
\text { United States }\end{array}$ & $\begin{array}{l}\text { Whole site } \\
\text { eradication }\end{array}$ & $\begin{array}{l}\text { Zequanox, } \\
\text { EarthTec QZ } \\
\text { Potassium chloride }\end{array}$ & 23 days & 8 months & $\$ 64,000$ & $\mathrm{~N}$ & Lund et al., 2018 \\
\hline
\end{tabular}

the barrage, that require annual maintenance to remove zebra mussel build-up.

The objectives of the study were (1) to assess the extent of seasonal and spatial variation in the growth and settlement rates of zebra mussel in a recently colonized artificial lake area, (2) to identify the conditions that are most favorable for zebra mussel production, and (3) to test for the existence of density-dependent growth. Ultimately, the aim of our study was to inform the development of more efficient control measures for zebra mussel by acting on those periods and locations where zebra mussel production is highest.

\section{MATERIALS AND METHODS}

\section{Study Area}

The study site, Cardiff Bay, is a $2.0 \mathrm{~km}^{2}$ amenity lake (depth $=4$ $7 \mathrm{~m}$ ) located in Cardiff (Wales, United Kingdom) and fed by two rivers (River Taff and River Ely). It was built between 1994 and 1999 as part of a regeneration project of the old docklands areas of Cardiff and Penarth. The site has been described in detail by Alix (2010), Alix et al. (2016). The lowermost section of the rivers Taff and Ely, in the vicinity of the Bay, contain zebra mussels, most likely transported upstream by boats. However, weirs and low bridges prevent extensive upstream movement. The National Biodiversity Network Atlas for Wales shows no upstream records of zebra mussels on the rivers Taff or Ely (NBN Atlas Wales, 2020), and the species was never reported in the rivers before it appeared in the Bay.

\section{Sampling Strategy}

We deployed four experimental buoys in different parts of Cardiff Bay (Figure 1), each buoy consisting of a weighted rope and three white plastic panels (A4 size, $210 \times 297 \mathrm{~mm}$ ) set at the surface $(0 \mathrm{~m}), 1 \mathrm{~m}$, and $3 \mathrm{~m}$ depth (Figure 2). The buoys were deployed on June 2017 and were monitored monthly until May 2018. The sites varied in depth between $3.3 \mathrm{~m}$ and $7.3 \mathrm{~m}($ mean $=5.1 \mathrm{~m}$, $\mathrm{SE}=0.84)$, had moderate to slow flows, little aquatic vegetation, and differed in the abundance of veligers and adult zebra mussels found in a previous study (Table 2), who also reported monthly means (SE) of Chlorophyll $a$ ( $\mu$ g.l-1) ranging between $4.3 \pm 1.7$ in May and $10.5 \pm 2.7$ in June and water velocity in February ranging between 4.4 and $12.2 \mathrm{~cm} / \mathrm{s}$ (Alix et al., 2016).

An area corresponding to $25 \%$ of each panel (i.e., $156 \mathrm{~cm}^{2}$ ) was scraped clean every month and all attached mussels were counted and measured. These are referred to as "clean samples" and provide data on the number and size of new recruits. A total of 141 scrape samples were collected in this way over the 12 months of the study, 43 of which contained zebra mussels (30.5\%). In addition, 81 scrape samples were obtained from colonized sections of the panel (i.e., let undisturbed, never scraped before) 5 months after the start of the study; each month a different area of the panel was scraped, 67 of which contained zebra mussel (82.7\%). Specimens were preserved in $70 \%$ ethanol and brought to the laboratory where they were counted and measured (shell length along the longest axis, $\mathrm{mm}$ ).

During the monthly monitoring, water parameters (temperature, DO concentration, $\mathrm{DO} \%$, salinity, conductivity, $\mathrm{pH}$, turbidity) were measured at $0 \mathrm{~m}, 1 \mathrm{~m}$, and $3 \mathrm{~m}$ depth at each sampling station with a probe (YSI Water Quality Sonde,6600 EDS V2, United States). Buoy B was lost during the last month of the experiment but data were available for 11 of the 12 months of the study.

\section{Statistical Analysis}

Statistical analyses were carried out using $\mathrm{R}$ version 3.3 ( $\mathrm{R}$ Core Team, 2017) and PAST v. 3.2.2 (Hammer et al., 2001). We used mixture analysis on shell length at the end of the growing season to estimate the number of different cohorts (age classes) that had colonized our experimental panels. For this, we varied the number of putative cohorts from 1 to 8 and chose the most likely number based on changes in AIC values (Hammer et al., 2001). We used linear models to examine variation in mussel size and density using month, depth and site as predictors. To examine the influence of water parameters, we used principal component analysis using the prcomp function in the factoextra $\mathrm{R}$ package (Kassambara and Mundt, 2017) and used the coordinates of the first principal component as predictors of mussel size and density in a linear mixed effect model using sampling station as a random factor, as above. Model simplification was achieved by examining 


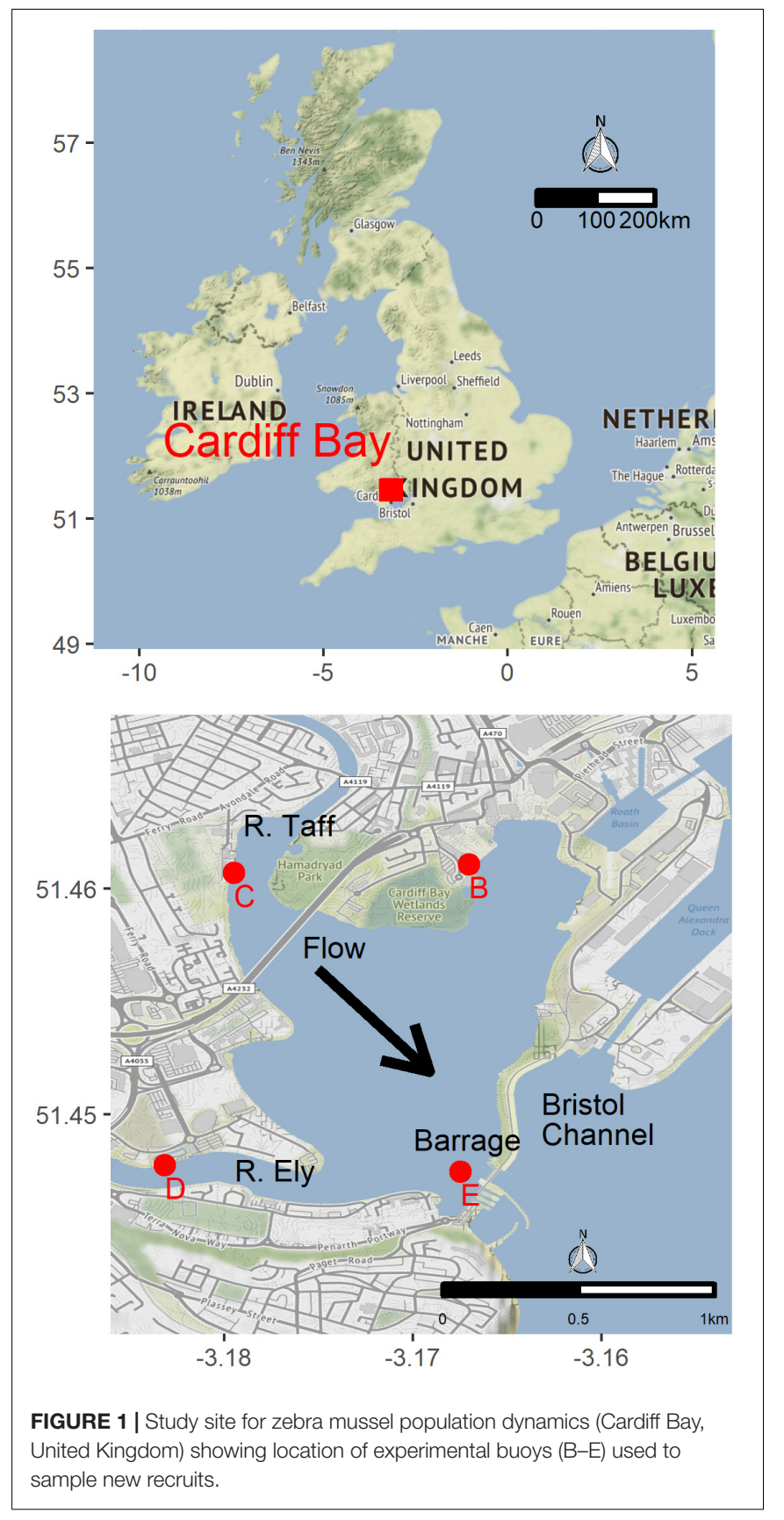

changes in AIC using the step and dredge functions, followed by Maximum Likelihood comparisons of nested models with the anova command.

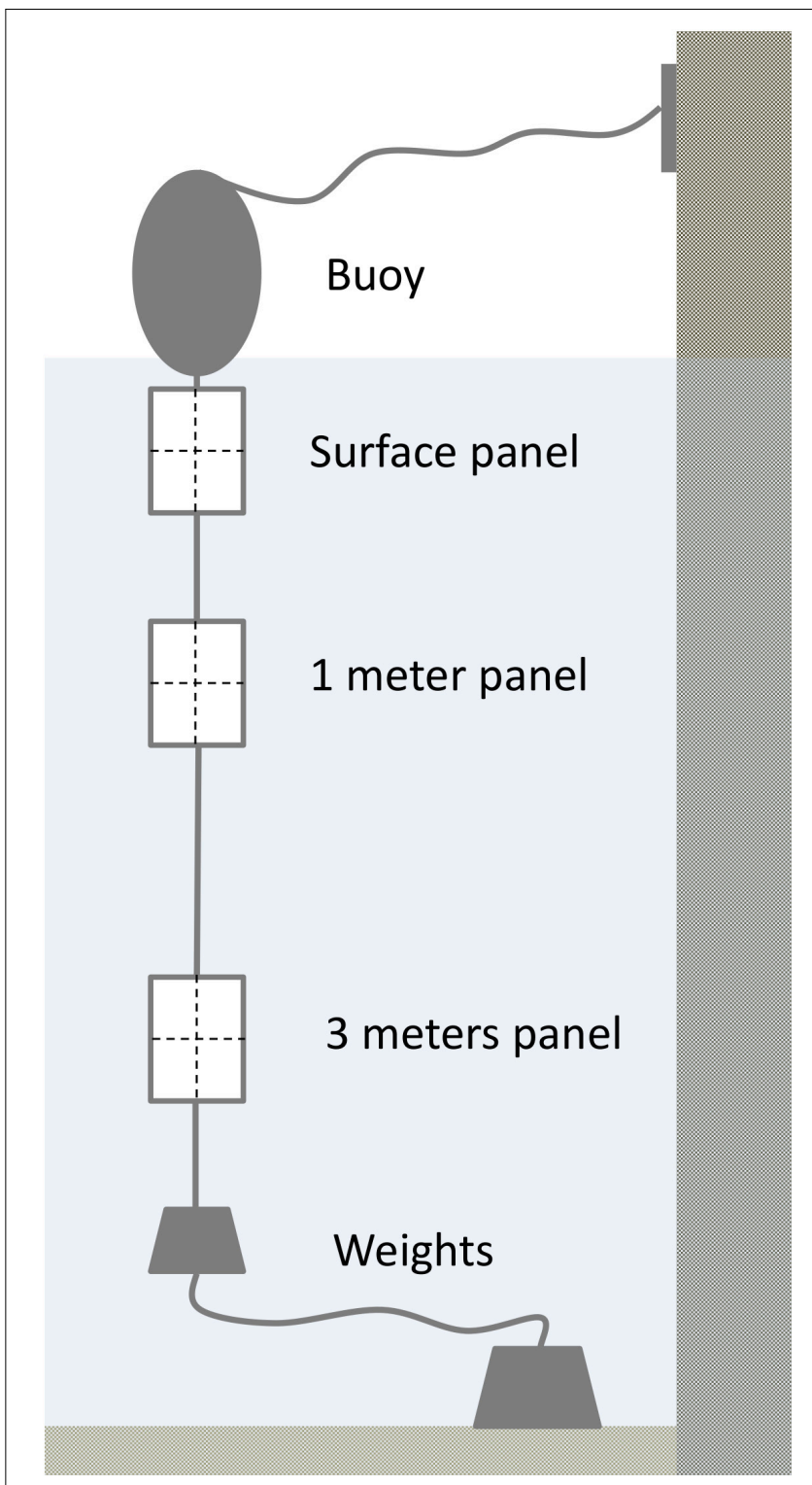

FIGURE 2 | Experimental buoys used to assess the influence of water depth and density on zebra mussel population dynamics. Each month 25\% of the area of each side-panel $\left(156 \mathrm{~cm}^{2}\right)$ was scrapped clean and all the attached zebra mussels were counted and measured.

To test for evidence of density-dependence, we analyzed if density was a significant predictor of the average size of mussels in each sample, taking into account the effects of

TABLE 2 | Characteristics of the four sampling sites and presence of veligers and adults of zebra mussel reported in a previous study (Alix et al., 2016).

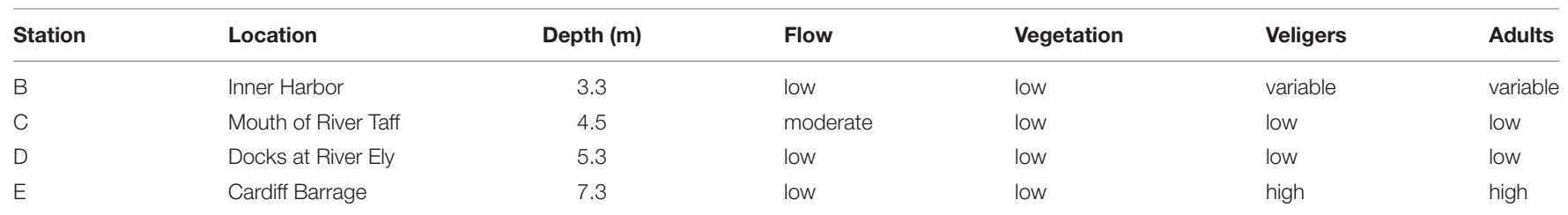


season, water depth, and variation among sites. We carried out an analysis separately for 1 month old mussels (originating from our monthly scrape panels) and for mussels sampled from undisturbed panel-sections at the end of the growing season. As the relation between density and size was not linear, we employed generalized additive modeling (GAM) using a penalized regression spline fitted by REML in the mgcv package to account for non-linearity (Wood, 2001), and dropped nonsignificant terms from the final model. We excluded site B from analysis as there was no colonization of the surface panel in any month, and used the gam.check command to assess departures from model assumptions.

\section{RESULTS}

\section{Variation in Water Chemistry}

Water chemistry changed both seasonally (Figure 3) and spatially across Cardiff Bay. Water temperatures peaked in
July-September $\left(\max =20.4^{\circ} \mathrm{C}\right)$ and reached a low in March $\left(\min =5.6^{\circ} \mathrm{C}\right.$; month $\left.F_{11,207}=1055.6, P<0.001\right)$, being generally warmest at the mouth of the River Ely (site D) and the barrage (site E), and coldest at the mouth of the River Taff (site C) and the inner harbor (site $\mathrm{B}, F_{3,207}=23.1, P<0.001$ ). Dissolved oxygen reached a minimum in July $(\mathrm{min}=6.1 \mathrm{mg} / \mathrm{L})$, coinciding with the warmest temperature $\left(F_{11,207}=1055.6\right.$, $P<0.001$ ), and was highest at the outlet of the Bay (site E), and lowest at site $\mathrm{D}\left(F_{3,207}=23.1, P<0.001\right)$. The four other water chemistry parameters also varied significantly from month to month, as well as from site to site (conductivity: month $F_{11,207}=1055.6, P<0.001$, site $F_{3,207}=23.1, P<0.001$; $\mathrm{pH}$ : month $F_{11,207}=1055.6, P<0.001$, site $F_{3,207}=23.1$, $P<0.001$; salinity: month $F_{11,207}=1055.6, P<0.001$, site $F_{3,207}=23.1, P<0.001$; turbidity: month $F_{11,207}=1055.6$, $P<0.001$, site $\left.F_{3,207}=23.1, P<0.001\right)$. However, no significant variation in water chemistry was found with respect to water depth, at least within the first $3 \mathrm{~m}(P>0.5$ in all models).
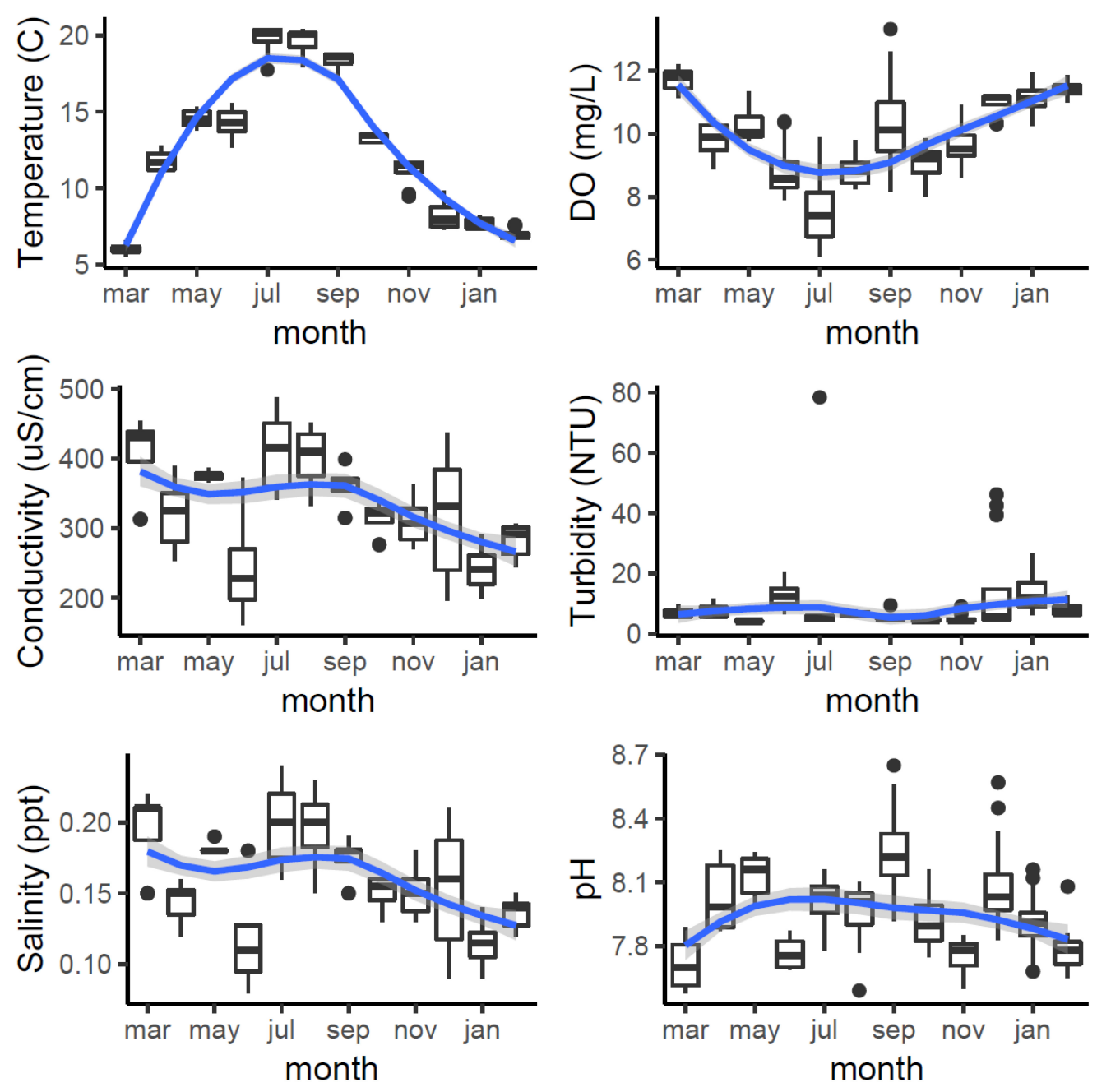

FIGURE 3 | Monthly variation in water chemistry in Cardiff Bay during the course of the study showing median values and interquartile range (boxplots) and smoothed fitted trends with 95Cl envelopes (blue and gray bands). 
Principal component analysis indicated that the first component (PC1) accounted for $39 \%$ of the variation in water chemistry parameters, but was not a significant predictor of either the average size $(t=0.787, P=0.434)$ or density $(t=2.46$, $P=0.750)$ of new recruits colonizing the experimental panels.

\section{Density and Settlement Rates}

Densities of 1 month old mussels sequentially sampled during the reproductive season varied between 0 in June and 1.8 individuals $/ \mathrm{cm}^{2}$ in September (Figure 4). Colonization of the experimental panels began in July, peaked during September and October, and then decreased rapidly, so that by November no new recruits were detected in any of the panels (Figure 4). Densities of 1 month old zebra mussel varied significantly between months $\left(F_{1,134}=15.8, P<0.001\right)$, sampling sites $\left(F_{3,134}=4.02, P=0.009\right)$, and depths $\left(F_{2,134}=3.46, P=0.03\right)$. The surface panels had the lowest number of recruits, while the deepest panel had the highest.

Densities in the undisturbed panels, sampled over the winter, also varied between sampling sites $\left(F_{3,75}=87.3, P<0.001\right)$

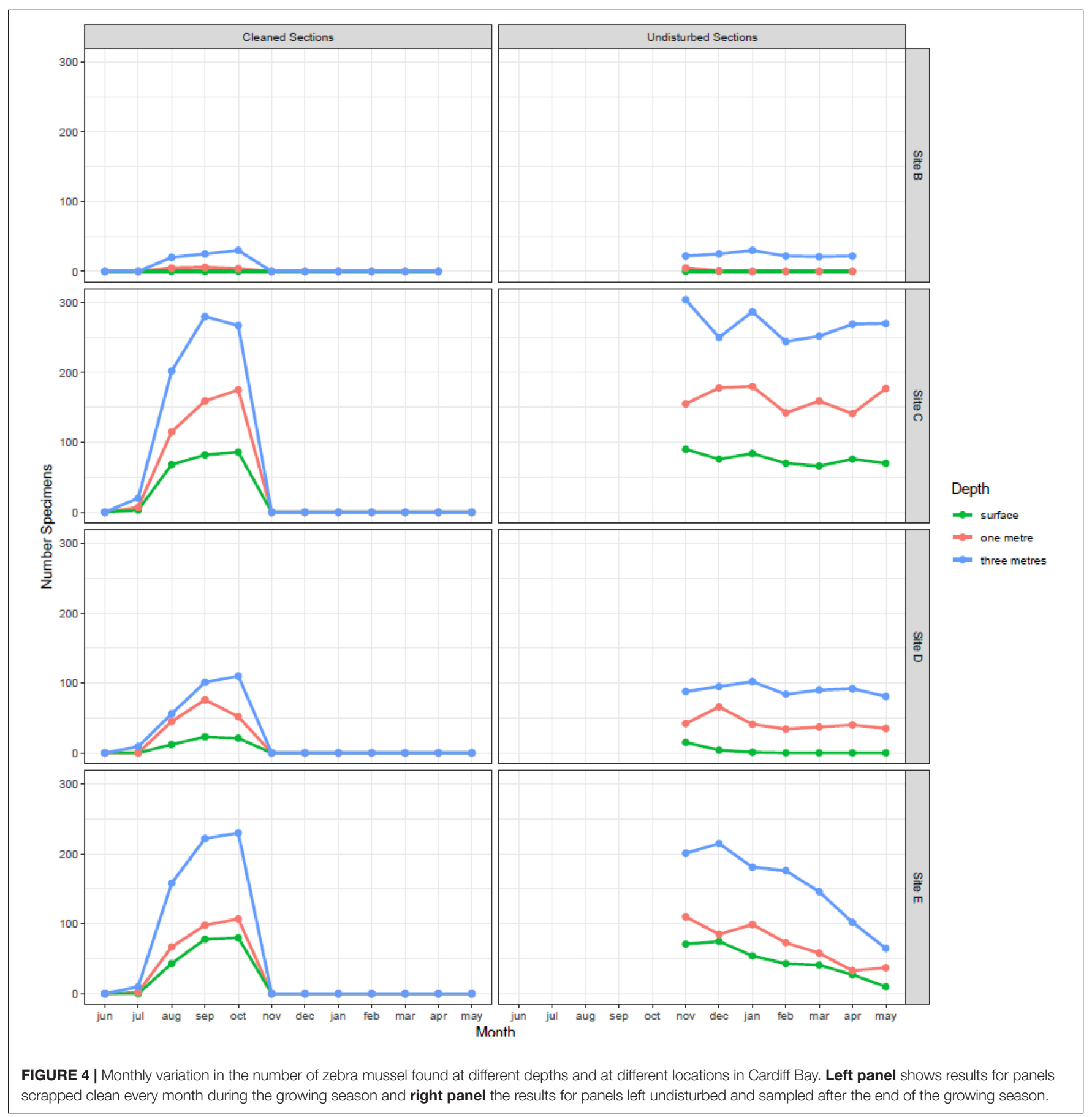


and depths $\left(F_{2,75}=71.2, P<0.001\right)$, but were stable across time (month $F_{6,69}=1.67, P=0.142$ ), confirming the lack of recruitment observed between November and May. In general, the highest densities and settlement rates were found at the mouth of the River Taff (site C) and at the outlet at the barrage (site E), while the lowest were found at the inner harbor (site B).

Settlement rates across the Bay followed a marked seasonal cycle (Figure 5), closely tracking variation in water temperature, beginning in June when temperature reached $14^{\circ} \mathrm{C}$, peaking in August and September, and then ceasing when temperature dropped below $14^{\circ} \mathrm{C}$ in October-November. Across sampling stations, settlement rates were $0.42-0.62$ individuals $\mathrm{cm}^{2}$ month $^{-1}$, with peaks of 1.790 individuals $\mathrm{cm}^{2}$ month $^{-1}$. This is equivalent to 4,200-6,200 mussels per $\mathrm{m}^{2}$ (peaks of 18,000 individuals $/ \mathrm{m}^{2}$ ).

\section{Determinants of Mussel Size and Growth}

The average size of 1 month old mussels colonizing the clean panels during the reproductive season varied between $9 \mathrm{~mm}$ in July and $21 \mathrm{~mm}$ in October, and differed significantly between months $\left(F_{3,1377}=700.7, P<0.001\right)$, sampling sites $\left(F_{3,1377}=293.3, P<0.001\right)$, and also with depth $\left(F_{1,1377}=385.4\right.$, $P<0.001$; Figure 6). The largest mussels were found at the mouth of the River Taff (site C) and at the outlet at the barrage (site E), while the smallest ones were found at the mouth of the River Ely (site D). Growth increased rapidly from July to October, and then plateaued for the rest of the year. The size of mussels was largest at $3 \mathrm{~m}$ depth $(95 \mathrm{CI}=15.7-16.3 \mathrm{~mm}$ ) and smallest at the surface $(95 \mathrm{CI}=14.0-14.8 \mathrm{~mm})$. Such variation persisted in the undisturbed panels over the winter, after the reproductive season, as mussel size continued to vary significantly between months $\left(F_{6,2774}=11.6, P<0.001\right)$, sampling sites $\left(F_{3,2774}=170.9, P<0.001\right)$ and also with depth $\left(F_{1,2774}=206.8\right.$, $P<0.001$; Figure 6). Thus, the average size of mussels in April

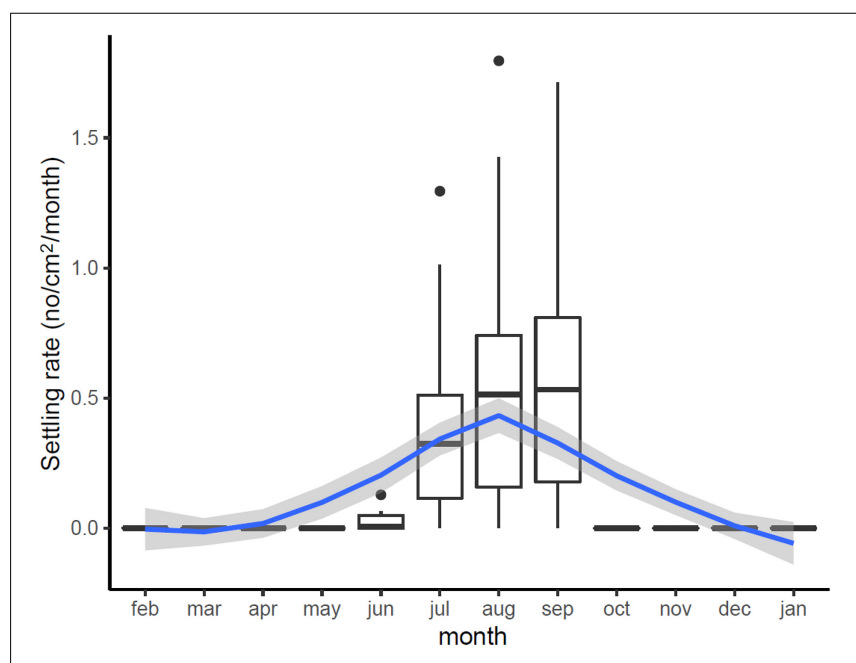

FIGURE 5 | Estimated variation in monthly settling rates (No. new recruits $/ \mathrm{cm}^{2} /$ month) across Cardiff Bay showing median values and interquartile range (boxplots) and smoothed fitted trend with $95 \mathrm{Cl}$ envelope (blue and gray bands).
2018, 10 months after the buoys were first deployed, was still significantly smaller at the surface $($ mean $=17.0 \mathrm{~mm})$ than at $1 \mathrm{~m}$ depth $($ mean $=18.3 \mathrm{~mm})$ and at $3 \mathrm{~m}$ depth $($ mean $=18.4 \mathrm{~mm}$; Tukey HSD $P$ adj $=0.003)$, which were not different among themselves (Tukey HSD, $P$ adj $=0.732$ ).

\section{Cohort Analysis}

Inspection of experimental panels revealed that new recruits were only found during July-October, suggesting that the reproductive season in Cardiff Bay likely extended from May or June to September. Results from mixture analysis suggest that the most plausible number of discrete cohorts colonizing the experimental panels over the course of the study was 5 age classes (Supplementary Figure S1), with an estimated age of approximately 2 months for the youngest settlers (size 11$12 \mathrm{~mm}$ ) to 330 days for the oldest ones when zebra mussels had already attained a size of 23-31 mm (Table 3). The distribution of cohorts varied significantly among sites (Chi-squared $=387.5$, $\mathrm{df}=12, P<0.001)$ and there were comparatively more younger settlers at the warmest sites (sites $\mathrm{D}$ and $\mathrm{E}$ ) than at the coldest ones (sites C and B, Figure 7).

\section{Density Dependence}

The size of 1 month old mussels (i.e., new settlers successively sampled from cleaned panels) was not affected by density, once the effects of site, water depth and month of sampling had been statistically controlled for (density $F_{1,29}=0.427$, $P=0.519)$. However, density was a significant predictor of mussel growth in the undisturbed panels (GAM estimates for smooth terms; density, $F_{3.357,4.090}=4.433, P=0.004$; density $\times$ site $C, F_{5.405,6.099}=14.881, P<0.001$; density $\times$ site $\mathrm{D}, F_{3.154,3.606}=16.688, P<0.001$; density $\times$ site $\mathrm{E}, F_{1,1}=3.732$, $P=0.06$; parametric terms, depth $1 \mathrm{~m}$ estimate $=0.466, \mathrm{SE}=0.05$, $t=9.266, P<0.001$; depth $3 \mathrm{~m}$ estimate $=0.759, \mathrm{SE}=0.07$, $t=10.267, P<0.001)$. The model explained $91.6 \%$ of deviance in mussel size, of which $39.4 \%$ was explained by density alone. Across sites, mussel size increased with density (Figure 8), but there were significant differences between sites. Thus, at sites with high recruitment (site $\mathrm{C}$, mouth of River Taff; site E, outlet of the barrage, Figure 5.) mussel size decreased at high densities, whereas at the site with low recruitment (site D, mouth of River Ely) the opposite was found (Figure 5). This suggests the existence of positive density-dependent growth at low densities, and negative density-dependent growth at high densities.

\section{DISCUSSION}

Our study indicates that within 14 years of being invaded, Cardiff Bay has a large, established population of zebra mussel, confirming the conclusions of a previous survey of veliger density using a different sampling approach (Alix et al., 2016). Our study also suggests that zebra mussel may be spatially structured into different cohorts that grow and settle at different rates. This has implications for management because if density, settlement rates, and growth vary spatially among locations, this creates the conditions necessary for zebra mussel metapopulations to 


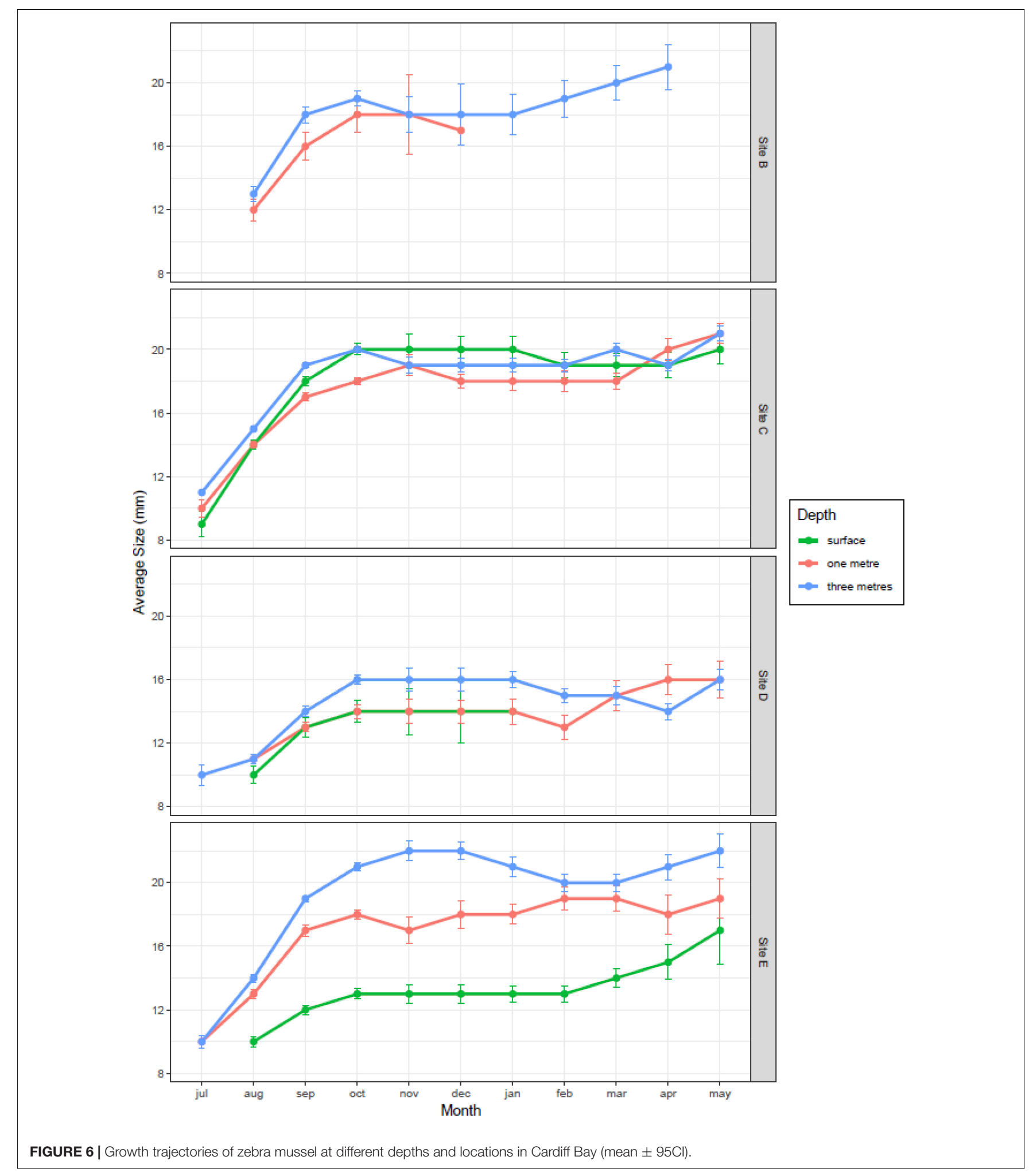

evolve, which would make control measures considerably more challenging (Mari et al., 2014).

Although the growth of zebra mussel on suspended substrates cannot be assumed to be representative of that on the bottom
(Karatayev et al., 2006, 2018), Cardiff Bay is rather shallow (mean $=4.5 \mathrm{~m}$; (Olivier, 2016) and our experimental panels extended to $41-91 \%$ of the water column (mean $=67 \%$ ). Most of the zebra mussel production in Cardiff Bay takes place on vertical 


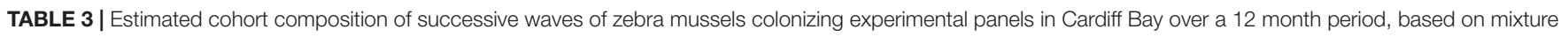
analysis of shell length frequency data $(n=2,785)$.

\begin{tabular}{|c|c|c|c|c|c|}
\hline Cohort & Approx. Age (days) & Mean size $(\mathrm{mm})$ & Size range $(\mathrm{mm})$ & SD & $\%$ Frequency \\
\hline 1 & 66 & 12.2 & $11-12$ & 0.85 & 7.3 \\
\hline 2 & 132 & 15.4 & $9-17$ & 2.02 & 47.2 \\
\hline 3 & 198 & 18.6 & $18-19$ & 0.57 & 17.3 \\
\hline 4 & 264 & 21.5 & $20-22$ & 0.84 & 12.2 \\
\hline 5 & 330 & 25.0 & 23-31 & 2.12 & 15.9 \\
\hline
\end{tabular}

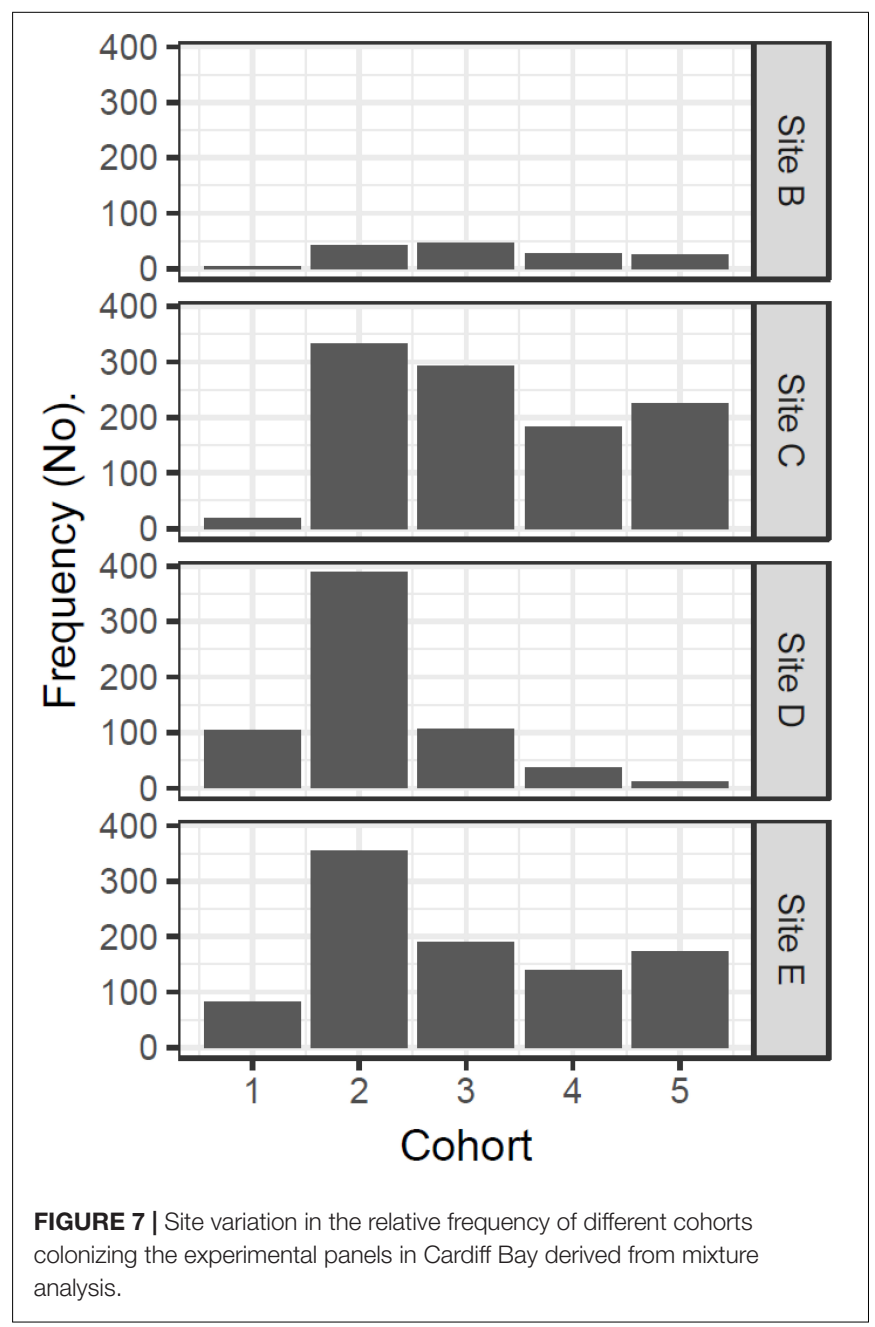

substrates, including submerged margins, piers, docks, and boat hulls that our panels tried to mimic. Zebra mussel have only been recorded on the bottom of Cardiff Bay on the aeration system or in small scattered patches (Alix et al., 2016), as the Bay has a high deposition rate of mud and silt (Vaughan et al., 2008; Olivier, 2016), which typically prevents settlement of juvenile mussels (Alix et al., 2016).

By carrying out monthly scrapes in artificial substrates, we have shown that zebra mussel began to settle in Cardiff Bay in July, 1 month after we deployed the experimental panels, and continued until October, with no evidence of new colonizations from November to May. Density and growth followed the same pattern, increasing over the summer and ceasing in October, after which no further recruitment or growth occurred. These findings are similar to those of previous studies (Fong et al., 1995; Ram et al., 1996; Alix et al., 2016), although there is large variation in the timing of reproduction and settlement of zebra mussel populations depending on temperature (Pollux et al., 2010). The fastest growth in Cardiff Bay was generally observed at the deepest waters $(3 \mathrm{~m})$, which also coincides with the highest settlement rates of new recruits. This strongly suggests that conditions that favor growth of zebra mussel also favor their survival. However, no significant differences in water chemistry were found within the first $3 \mathrm{~m}$, despite a large variation in growth and settlement rates within the water column and our index of water chemistry (PC1) did not explain the size or abundance of mussels, despite large variation in water parameters among sites. This suggests that factors other than water chemistry control growth and colonization of zebra mussel, most likely physical disturbance, food abundance and UV exposure. Water parameters for Cardiff Bay are within the optimal values for zebra mussel (Kilgour et al., 1994; Spidle et al., 1995; Bowman and Bailey, 1998). However, the Bay is fitted with a bottom aeration system to maintain high dissolved oxygen and permit the passage of migratory Atlantic salmon and brown trout (Alix et al., 2016), and as a result, water is more mixed than would normally be, which may explain the apparent lack of stratification in water parameters (Alix, 2010).

The low settlement rate of mussels found in surface samples has been noted previously in laboratory and field studies (Kobak, 2001, 2004; Alix et al., 2016). Veligers appear to be absent from the upper $50 \mathrm{~cm}$ of the water column in Cardiff Bay (Alix et al., 2016). Avoidance of surface waters appears to be related to light intensity (Kobak, 2001; Seaver et al., 2009) and may confer mussels some protection against bird predators and desiccation caused by fluctuating water levels. For example, Alix (2010) reported that waterfowl fed on surface mussels in Cardiff Bay and has also been found that waves reduce settlement rates (Chase and Bailey, 1999; Kobak, 2004), which may explain the low abundance of mussels in our surface panels. Mean settlement rates varied between 4,200 and 6,200 mussels $\mathrm{m}^{-2}$ month $^{-1}$, which are similar to those reported for well established populations elsewhere (Cleven and Frenzel, 1993; Stanczykowska and Lewandowski, 1993; Mackie and Schloesser, 1996), and are also consistent with adult densities of 450-5,100 mussels $\mathrm{m}^{-2}$ estimated at Cardiff Bay during 2006-2009 (Alix, 2010; Alix et al., 2016). However, the peak of 17,960 adult mussels $\mathrm{m}^{-2}$ month $^{-1}$ 

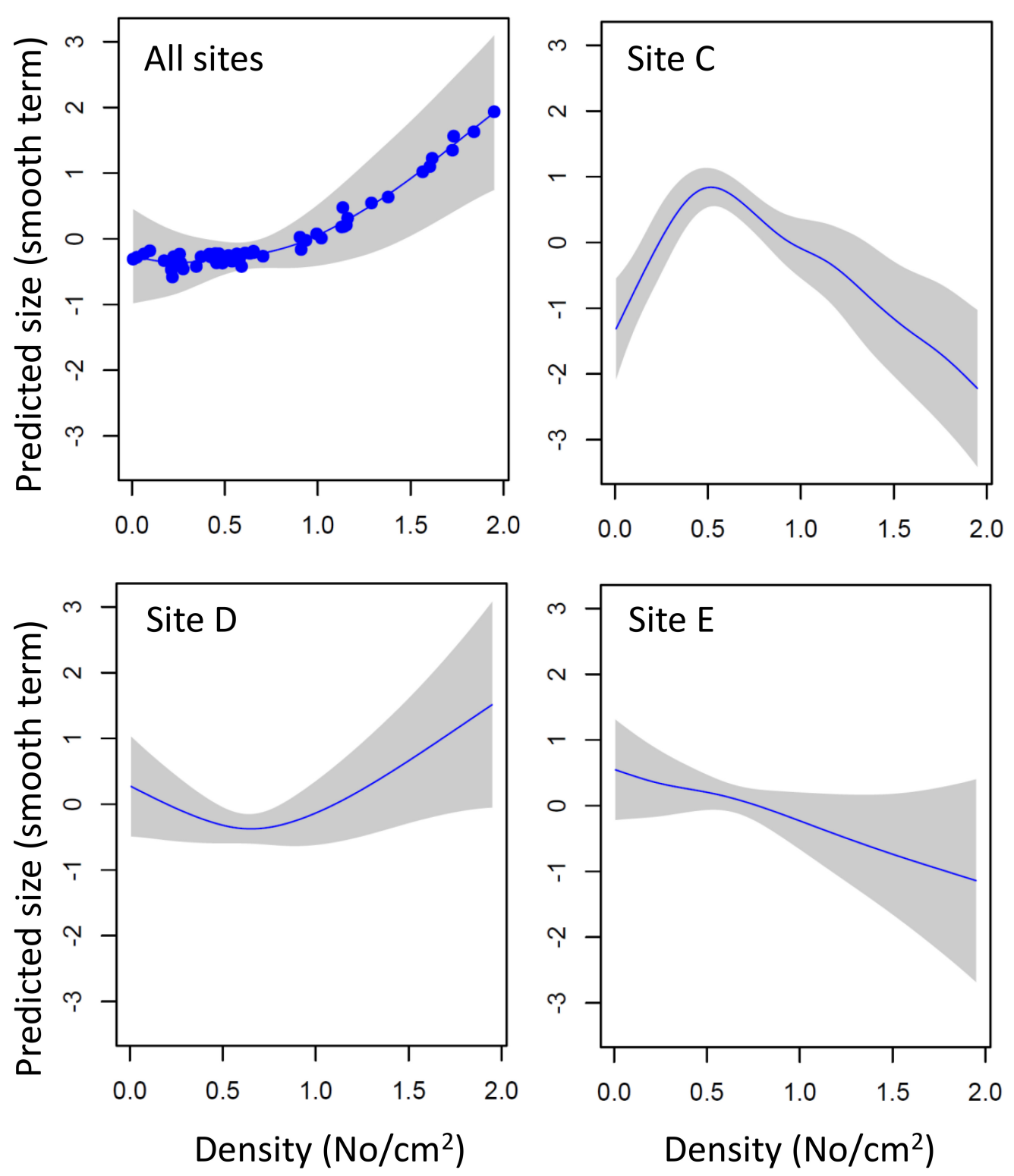

FIGURE 8 | Density-dependent changes in the growth of zebra mussel in different parts of Cardiff Bay. Shown are predicted sizes (GAM smoothed term centered around zero) and $95 \mathrm{Cl}$ envelopes across All sites, at sites with high recruitment (Sites $\mathbf{C , E}$ ) and at a site of low recruitment (site D).

recorded on September 2017 at a depth of $3 \mathrm{~m}$ at the mouth of the river Taff (site $\mathrm{C}$ ) is over 2.3 times higher than the highest value reported previously for Cardiff Bay $\left[7,700\right.$ individuals $\mathrm{m}^{-2}-$ Alix et al. (2016)], and also higher than the highest density ever recorded in Britain [11,000 individuals $\mathrm{m}^{-2}$, - Aldridge et al. (2004)]. This may indicate that the zebra mussel population in Cardiff Bay is increasing despite the removal of approximately 4 tonnes of mussels every year (Alix et al., 2016).

Our results suggest the existence of five distinct cohorts resulting from the same spawning season, that our data suggest it extends from June to September (Figure 5). This is in agreement with results from previous surveys on veliger density that also indicated a reproductive season extending from late May/June to late September/October for Cardiff Bay (Alix et al., 2016). The presence of multiple cohorts from the same spawning season has not been reported previously but is consistent with results from the laboratory that indicate that the release of gametes occurs over 2-6 spaced events (Walz, 1978; Haag and Garton, 1992). It can also result from spatial variation in the timing of reproduction and growth across the Bay, as well as from dispersal at the post-settlement adult stage. Dispersal of zebra mussels is mostly through the planktonic veliger stage but settled adults can also disperse. Adults may choose to dislodge when conditions become unsuitable and be transported long distances attached to macrophytes and other vectors, and also drift using the byssus to gain buoyancy (Martel, 1993; Kobak, 2001). This means that 
colonization is not restricted to the veliger stage immediately after reproduction, but that it can be extended beyond this phase. Post-settlement dispersal, therefore, coupled with variation in timing of reproduction among locations and multiple releases of gamete could give rise to multiple cohorts and different waves of settlers, as observed in our study. More generally, variation in habitat quality, timing of reproduction and demography creates the conditions necessary for source and sink metapopulations to develop (Stoeckel et al., 1997) which may need to be taken into account in the management of zebra mussel. For example, our results suggest that different density dependent mechanisms may operate in different habitats, once the effects of depth and month of sampling have been taken into account.

In general, mussel size increased with density, but there were marked differences between sites. There was positive density-dependent growth at sites with low densities, and negative density-dependent growth at sites with high densities, suggesting some form of population regulation, presumably caused by competition. Zebra mussel settlement rates have been reported to be lower on substrate densely populated by adults (Nalepa et al., 1995) which is consistent with negative density dependence. Although river studies may not be extrapolated to lake populations, Strayer and Malcom (2006) found recruitment to be negatively related to the size of an adult river population, and showed how very rapid somatic growth could make some year-classes dominant and suppress recruitment of the next year class. Likewise, Mörtl and Rothhaupt (2003) reported a lower abundance of juveniles on substrates already colonized by adults, and suggested that adults were preying on veligers. These findings are consistent with negative density-dependence, as observed in our study. However, examples of more complex negative and positive density-dependence mechanisms have also been reported. For example, Chase and Bailey (1996) observed that veligers were chemically attracted to adult conspecifics and preferred to settle in high density areas, but only within certain densities. When densities were too high, veligers chose the lower densities, suggesting the existence of density thresholds and different density-dependent relationships. These results could have implications for management because removal could be beneficial or counter-productive depending on density thresholds and conditions.

The cost of controlling zebra mussel populations is generally high (Adams and Lee, 2012) and while different eradication methods have been tested in the laboratory (Costa et al., 2011; Watters et al., 2013; Claudi et al., 2014; Luoma et al., 2015) these are not always successful in the field (Table 1). The development of more efficient eradication methods should benefit from insights into natural factors regulating population growth (Lund et al., 2018). Currently, control measures against zebra mussel are limited to the use of various chemicals (Glomski, 2015), ultraviolet radiation (Lewis and Whitby, 1997) and mechanical removal and drying (Durán et al., 2010). These aim to reduce populations size, but our results may help explain why removal may not always work. Zebra mussels often follow boom and bust population dynamics (Stanczykowska, 1977; Burla and Ribi, 1998; Casagrandi et al., 2007; Strayer et al., 2017), but the underlying drivers of population regulation are not clear. Several predators feed on zebra mussel (Wisniewski, 1974; Pedroli, 1977; Petrie and Knapton, 1999; Werner et al., 2005; Naddafi and Rudstam, 2014), but "natural enemies" alone are unlikely to regulate zebra mussel populations (Molloy et al., 1997). Densitydependent drivers like disease outbreaks (Strayer and Malcom, 2006), or food depletion caused by mussel filtration (Karatayev et al., 2018) are thought to play a much greater role in regulating the abundance of zebra mussel. Whatever the reasons, we suggest that since complete eradication will seldom be possible, local zebra mussel populations dynamics should be considered before embarking on partial removal as this may prove expensive, ineffectual, and may in some cases enhance production and aggravate the problem.

In conclusion, our results indicate that the zebra mussel is a well established aquatic invader in Cardiff Bay and despite periodic removal, its numbers appear to be growing as evidenced by having the highest densities recorded in Britain to date, and also higher than previous estimates for this artificial water body. Given the overriding effect of water temperature on reproduction, under current predictions of climate change the spawning period of zebra mussel in Cardiff Bay will likely extend, which may result in even higher production. This makes the search for more effective control measures paramount. Based on the observed seasonal pattern of growth and recruitment, we suggest that control measures might benefit from targeting the summer and early autumn for removal of zebra mussel, as this appears to be the most critical period for the colonization and dispersal of this invasive species. We also suggest that control actions should target suitable structures located $3 \mathrm{~m}$ deep or deeper, as this appears to be the zone where most of the zebra mussel production occurs. However, the existence of contrasting patterns of density dependent growth (positive at sites of low recruitment and negative at sites of high recruitment) suggests that removal of adult mussels may help curtail biomass production at some sites but may enhance it at other sites. The existence of significant spatial variation in growth and settlement rates across the Bay, coupled with multiple cohorts, suggest that zebra mussel might be structured as a metapopulation governed by source and sink dynamics (Stoeckel et al., 1997). Although our study cannot resolve this possibility, this merits further attention and could be addressed by using molecular markers to determine patterns of gene flow (e.g., Therriault et al., 2005).

\section{DATA AVAILABILITY STATEMENT}

The datasets generated by this study are available on Figshare https://doi.org/10.6084/m9.figshare.8216279.v1.

\section{ETHICS STATEMENT}

The animal study was reviewed and approved by the Swansea University College of Science Ethics Committee Permit Student 210519/1557. 


\section{AUTHOR CONTRIBUTIONS}

CG and SC designed the study and secured the funding. MR collected the data and carried out the analyses with advice from CG. MR and CG wrote the manuscript with contributions from SC and DH.

\section{FUNDING}

Funding was provided by the EC Horizon 2020 AquainvadED project (Marie Skłodowska-Curie ITN-2014-ETN-642197) to SC. This manuscript has been released as a pre-print at

\section{REFERENCES}

Adams, D. C., and Lee, D. J. (2012). Technology adoption and mitigation of invasive species damage and risk: application to zebra mussels. J. Bioecon. 14, 21-40. doi: 10.1007/s10818-011-9117-x

Aldridge, D. C., Elliott, P., and Moggridge, G. D. (2004). The recent and rapid spread of the zebra mussel (Dreissena polymorpha) in great Britain. Biol. Conserv. 119, 253-261. doi: 10.1016/j.biocon.2003.11.008

Aldridge, D. C., Elliott, P., and Moggridge, G. D. (2006). Microencapsulated BioBullets for the control of biofouling zebra mussels. Environ. Sci. Technol. 40, 975-979. doi: 10.1021/es050614+

Alix, M. (2010). Zebra Mussel (Dreissena polymorpha) Population in the Newly Formed Cardiff Bay. PhD thesis, Cardiff University, Cardiff.

Alix, M., Knights, R., and Ormerod, S. J. (2016). Rapid colonisation of a newly formed lake by zebra mussels and factors affecting juvenile settlement. Manag. Biol. Invasions 7, 405-418. doi: 10.3391/mbi.2016.7.4.10

Allen, Y. C., Thompson, B. A., and Ramcharan, C. W. (1999). Growth and mortality rates of the zebra mussel, Dreissena polymorpha, in the Lower Mississippi River. Can. J. Fish. Aquat. Sci. 56, 748-759. doi: 10.1139/f98-212

Baker, S., and Hornbach, D. (1997). Acute physiological effects of zebra mussel (Dreissena polymorpha) infestation on two unionid mussels, Actiononaias ligamentina and Amblema plicata. Can. J. Fish. Aquat. Sci. 54, 512-519. doi: 10.1139/f96-319

Bastviken, D. T., Caraco, N. F., and Cole, J. J. (1998). Experimental measurements of zebra mussel (Dreissena polymorpha) impacts on phytoplankton community composition. Freshwat. Biol. 39, 375-386. doi: 10.1046/j.1365-2427.1998.00 283.x

Berkman, P. A., Haltuch, M. A., Tichich, E., Garton, D. W., Kennedy, G. W., Gannon, J. E., et al. (1998). Zebra mussels invade Lake Erie muds. Nature 393:27. doi: 10.1038/29902

Bodamer, B. L., and Bossenbroek, J. M. (2008). Wetlands as barriers: effects of vegetated waterways on downstream dispersal of zebra mussels. Freshwat. Biol. 53, 2051-2060. doi: 10.1111/j.1365-2427.2008.02027.x

Bowman, M. F., and Bailey, R. (1998). Upper pH tolerance limit of the zebra mussel (Dreissena polymorpha). Can. J. Zool. 76, 2119-2123. doi: 10.1139/z98-155

Britton, D. K. (2015). "History of western management actions on invasive mussels," in Biology and Management of Invasive Quagga and Zebra Mussels in the Western United States, eds W. H. Wong, and S. L. Gerstenberger (Boca Raton: CRC Press), 23-34.

Burla, H., and Ribi, G. (1998). Density variation of the zebra mussel Dreissena polymorpha in Lake Zürich, from 1976 to 1988. Aquat. Sci. 60, 145-156. doi: 10.1007/PL00001315

Casagrandi, R., Mari, L., and Gatto, M. (2007). Modelling the local dynamics of the zebra mussel (Dreissena polymorpha). Freshwat. Biol. 52, 1223-1238. doi: 10.1111/j.1365-2427.2007.01761.x

Chase, M., and Bailey, R. (1996). Recruitment of Dreissena polymorpha: does the presence and density of conspecifics determine the recruitment density and pattern in a population? Malacologia 38, 19-31.

Chase, M. E., and Bailey, R. C. (1999). The ecology of the zebra mussel (Dreissena polymorpha) in the lower Great Lakes of North America: I. Population dynamics
bioRxiv, Rolla et al. (2019) https://www.biorxiv.org/content/10. 1101/656371v1.

\section{SUPPLEMENTARY MATERIAL}

The Supplementary Material for this article can be found online at: https://www.frontiersin.org/articles/10.3389/fevo.2020.00159/ full\#supplementary-material

FIGURE S1 | Determination by mixture analysis of the most likely number of zebra mussel cohorts colonizing the experimental panels in Cardiff Bay (undisturbed panels) showing (A) changes in AIC values depending on number of putative cohorts, and (B) mean size ( $\pm \mathrm{SD}$ ) of the smallest cohort (cohort 1).

and growth. J. Great Lakes Res. 25, 107-121. doi: 10.1016/S0380-1330(99) 70720-3

Churchill, C. J., Hoeinghaus, D. J., and La Point, T. W. (2017). Environmental conditions increase growth rates and mortality of zebra mussels (Dreissena polymorpha) along the southern invasion front in North America. Biol. Invasions 19, 2355-2373. doi: 10.1007/s10530-017-1447-8

Claudi, R., and Mackie, G. L. (1993). Practical Manual for the Monitoring and Control of Macrofouling Mollusks in Fresh Water Systems. Boca Raton, FL: CRC Press.

Claudi, R., Prescott, T., Mastisky, S., and Coffey, H. (2014). Efficacy of Copper Based Algaecides for Control of Quagga and Zebra Mussels. Picton, ON: RNY Consulting Report prepared for California Department of Water Resources, Aquatic Nuisance Species Program.

Cleven, E.-J., and Frenzel, P. (1993). Population dynamics and production of Dreissena polymorpha (Pallas) in River Seerhein, the outlet of Lake Constance (Obersee). Arch. Hydrobiol. 127, 395-407.

Costa, R., Aldridge, D., and Moggridge, G. (2011). Preparation and evaluation of biocide-loaded particles to control the biofouling zebra mussel, Dreissena polymorpha. Chem. Eng. Res. Des. 89, 2322-2329. doi: 10.1016/j.cherd.2011. 02.027

Decksbach, N. (1935). Dreissena polymorpha - Verbreitung im europäischen Teile der UdSSR und die sie bedingenden Faktoren: Mit 1 Karte. Verh. Internat. Verein. Limnol. 7, 432-438. doi: 10.1080/03680770.1935.11898571

Durán, C., Lanao, M., Anadón, A., and Touyá, V. (2010). Management strategies for the zebra mussel invasion in the Ebro River basin. Aquat. Invasions 5, 309-316. doi: 10.3391/ai.2010.5.3.09

Fahnenstiel, G. L., Bridgeman, T. B., Lang, G. A., McCormick, M. J., and Nalepa, T. F. (1995). Phytoplankton productivity in Saginaw Bay, Lake Huron: effects of zebra mussel (Dreissena polymorpha) colonization. J. Great Lakes Res. 21, 464-475. doi: 10.1016/S0380-1330(95)71059-0

Fernald, R. T., and Watson, B. T. (2013). "Eradication of zebra mussels (Dreissena polymorpha) from Millbrook quarry, Virginia," in Quagga and Zebra Mussels: Biology, Impacts and Control, eds T. F. Nalepa, and D. W. Schloesser (Boca Raton, FL: Lewis Publishers), 195-214. doi: 10.1201/b15437-19

Fong, P. P., Kyozuka, K., Duncan, J., Rynkowski, S., Mekasha, D., and Ram, J. L. (1995). The effect of salinity and temperature on spawning and fertilization in the zebra mussel Dreissena polymorpha (Pallas) from North America. Biol. Bull. 189, 320-329. doi: 10.2307/1542149

Gallardo, B., Zu Ermgassen, P. S., and Aldridge, D. C. (2013). Invasion ratcheting in the zebra mussel (Dreissena polymorpha) and the ability of native and invaded ranges to predict its global distribution. J. Biogeogr. 40, 2274-2284. doi: $10.1111 /$ jbi.12170

Glomski, L. M. (2015). Zebra Mussel Chemical Control Guide, Version 2.0. Vicksburg, MS: Engineer research and development center.

Haag, W. R., and Garton, D. W. (1992). Synchronous spawning in a recently established population of the zebra mussel, Dreissena polymorpha, in western Lake Erie, USA. Hydrobiologia 234, 103-110. doi: 10.1007/BF000 10865

Hammer, $\varnothing$, Harper, D. A., and Ryan, P. D. (2001). PAST: paleontological statistics software package for education and data analysis. Palaeontol. Electron. 4:9. 
Hincks, S. S., and Mackie, G. L. (1997). Effects of pH, calcium, alkalinity, hardness, and chlorophyll on the survival, growth, and reproductive success of zebra mussel (Dreissena polymorpha) in Ontario lakes. Can. J. Fish. Aquat. Sci. 54, 2049-2057. doi: 10.1139/f97-114

Holland, R. E. (1993). Changes in planktonic diatoms and water transparency in Hatchery Bay, Bass Island area, western Lake Erie since the establishment of the zebra mussel. J. Great Lakes Res. 19, 617-624. doi: 10.1016/S0380-1330(93) 71245-9

Johnson, L. E., Ricciardi, A., and Carlton, J. T. (2001). Overland dispersal of aquatic invasive species: a risk assessment of transient recreational boating. Ecol. Appl. 11, 1789-1799. doi: 10.1890/1051-0761(2001)011\%5B1789:odoais\%5 D2.0.co; 2

Karatayev, A. Y., Burlakova, L. E., and Padilla, D. K. (1998). Physical factors that limit the distribution and abundance of Dreissena polymorpha (Pall.). J. Shellfish Res. 17, 1219-1235.

Karatayev, A. Y., Burlakova, L. E., and Padilla, D. K. (2006). Growth rate and longevity of Dreissena polymorpha (Pallas): a review and recommendations for future study. J. Shellfish Res. 25, 23-32. doi: 10.2983/0730-8000(2006)25\%5B23: gralod\%5D2.0.co;2

Karatayev, A. Y., Karatayev, V. A., Burlakova, L. E., Rowe, M. D., Mehler, K., and Clapsadl, M. D. (2018). Food depletion regulates the demography of invasive dreissenid mussels in a stratified lake. Limnol. Oceanogr. 63, 2065-2079. doi: 10.1002/lno.10924

Kassambara, A., and Mundt, F. (2017). Factoextra: Extract and Visualize the Results of Multivariate Data Analyses. R package version 1.4 (accessed May 15, 2020).

Kearney, M., and Morton, B. (1970). The distribution of Dreissena polymorpha (Pallas) in Britain. J. Conchol. 27, 97-100.

Kilgour, B. W., Mackie, G. L., Baker, M. A., and Keppel, R. (1994). Effects of salinity on the condition and survival of zebra mussels (Dereissena polymorpha). Estuaries 17:385. doi: 10.2307/1352671

Kinzelbach, R. (1992). The main features of the phylogeny and dispersal of the zebra mussel Dreissena polymorpha. Limnol. Aktuell 4, 5-17.

Kobak, J. (2001). Light, gravity and conspecifics as cues to site selection and attachment behaviour of juvenile and adult Dreissena polymorpha Pallas, 1771. J. Molluscan Stud. 67, 183-189. doi: 10.1093/mollus/67.2.183

Kobak, J. (2004). Recruitment and small-scale spatial distribution of Dreissena polymorpha (Bivalvia) on artificial materials. Arch. Hydrobiol. 160, 25-44. doi: 10.1127/0003-9136/2004/0160-0025

Lewis, D. P., and Whitby, G. E. (1997). Method and Apparatus for Controlling Zebra and Related Mussels Using Ultraviolet Radiation. US Patent 5,655,483. Washington, DC: U.S. Patent and Trademark Office.

Lovell, S. J., Stone, S. F., and Fernandez, L. (2006). The economic impacts of aquatic invasive species: a review of the literature. Agric. Econ. Res. Rev. 35, 195-208. doi: 10.1017/S1068280500010157

Lowe, S., Browne, M., Boudjelas, S., and De Poorter, M. (2000). 100 of the World's Worst Invasive Alien Species: A Selection From the Global Invasive Species Database. Auckland: Invasive Species Specialist Group.

Lund, K., Cattoor, K. B., Fieldseth, E., Sweet, J., and McCartney, M. A. (2018). Zebra mussel (Dreissena polymorpha) eradication efforts in Christmas Lake, Minnesota. Lake Reserv. Manag. 34, 7-20. doi: 10.1080/10402381.2017.136 0417

Luoma, J. A., Severson, T. J., Barbour, M. T., and Wise, J. K. (2018). Effects of temperature and exposure duration on four potential rapid-response tools for zebra mussel (Dreissena polymorpha) eradication. Manag. Biol. Invasions 9, 425-438. doi: 10.3391/mbi.2018.9.4.06

Luoma, J. A., Weber, K. L., Severson, T. J., and Mayer, D. A. (2015). Efficacy of Pseudomonas fluorescens strain CL145 A Spray Dried Powder for Controlling Zebra Mussels Adhering to Native Unionid Mussels Within Field Enclosures. Reston, VA: US Geological Survey Report.

Mackie, G. L., and Schloesser, D. W. (1996). Comparative biology of zebra mussels in Europe and North America: an overview. Am. Zool. 36, 244-258. doi: 10. 1093/icb/36.3.244

MacNeil, C., Platvoet, D., Dick, J. T., Fielding, N., Constable, A., Hall, N., et al. (2010). The Ponto-Caspian'killer shrimp', Dikerogammarus villosus (Sowinsky, 1894), invades the British Isles. Aquat. Invasions 5, 441-445. doi: 10.3391/ai. 2010.5.4.15

Mari, L., Bertuzzo, E., Casagrandi, R., Gatto, M., Levin, S. A., Rodriguez-Iturbe, I., et al. (2011). Hydrologic controls and anthropogenic drivers of the zebra mussel invasion of the Mississippi-Missouri river system. Water Resour. Res. 47:3. doi: 10.1029/2010WR009920

Mari, L., Casagrandi, R., Bertuzzo, E., Rinaldo, A., and Gatto, M. (2014). Metapopulation persistence and species spread in river networks. Ecol. Lett. 17, 426-434. doi: 10.1111/ele.12242

Martel, A. (1993). Dispersal and recruitment of zebra mussel (Dreissena polymorpha) in a nearshore area in west-central Lake Erie: the significance of postmetamorphic drifting. Can. J. Fish. Aquat. Sci. 50, 3-12. doi: 10.1139/ f93-001

Martel, A., Mathieu, A. F., Findlay, C. S., Nepszy, S. J., and Leach, J. H. (1994). Daily settlement rates of the zebra mussel, Dreissena polymorpha, on an artificial substrate correlate with veliger abundance. Can. J. Fish. Aquat. Sci. 51, 856-861. doi: 10.1139/f94-084

Meehan, S., Gruber, B., and Lucy, F. E. (2014). Zebra mussel control using Zequanox $^{\circledR}$ in an Irish waterway. Manag. Biol. Invasion 5, 279-286. doi: 10. 3391/mbi.2014.5.3.11

Minchin, D., and Moriarty, C. (1998). Zebra mussels in Ireland. Fish. Leafl. 177, $1-11$.

Minchin, D., Lucy, F., and Sullivan, M. (2002). "Zebra mussel: impacts and spread," in Invasive Aquatic Species of Europe. Distribution, Impacts and Management, eds E. Leppäkoski, S. Gollasch, and S. Olenin (Dordreicht: Springer), 135-146.

Molloy, D. P., Karatayev, A. Y., Burlakova, L. E., Kurandina, D. P., and Laruelle, F. (1997). Natural enemies of zebra mussels: predators, parasites, and ecological competitors. Rev. Fish. Sci. 5, 27-97. doi: 10.1080/10641269709388593

Mörtl, M., and Rothhaupt, K. O. (2003). Effects of adult Dreissena polymorpha on settling juveniles and associated macroinvertebrates. Int. Rev. Hydrobiol. 88, 561-569. doi: 10.1002/iroh.200310640

Naddafi, R., and Rudstam, L. G. (2014). Predation on invasive zebra mussel, Dreissena polymorpha, by pumpkinseed sunfish, rusty crayfish, and round goby. Hydrobiologia 721, 107-115. doi: 10.1007/s10750-013-1653-z

Nalepa, T. F., Cavaletto, J. F., Ford, M., Gordon, W. M., and Wimmer, M. (1993). Seasonal and annual variation in weight and biochemical content of the zebra mussel, Dreissena polymorpha, in Lake St. Clair. J. Great Lakes Res. 19, 541-552. doi: 10.1016/S0380-1330(93)71240-X

Nalepa, T. F., Wojcik, J. A., Fanslow, D. L., and Lang, G. A. (1995). Initial colonization of the zebra mussel (Dreissena polymorpha) in Saginaw Bay, Lake Huron: population recruitment, density, and size structure. J. Great Lakes Res. 21, 417-434. doi: 10.1016/S0380-1330(95)71056-5

NBN Atlas Wales (2020). D. Polymorpha. Available online at: https://wales-species. nbnatlas.org/species/NBNSYS0000006809 (accessed April 27, 2020).

OAFB (2009). Final summary report: Zebra Mussel Eradication Project, Lake Offutt Nebraska. Omaha, NE: OAFB (Offutt Air Force Base) prepared for 55 CES/CEV.

Olivier, M. F. (2016). Temperature and Salinity Controls on Methanogenesis in An Artificial Freshwater Lake (Cardiff Bay, Wales). PhD thesis, Cardiff University, Cardiff.

O’Neill, J. C. R. (1997). Economic impact of zebra mussels- results of the 1995 National Zebra Mussel Information Clearinghouse Study. Great Lakes Res. Rev. 3, 35-44.

Orlova, M., Khlebovich, V., and Komendantov, A. Y. (1998). Potential euryhalinity of Dreissena polymorpha (Pallas) and Dreissena bugensis (Andr.). Russ. J. Aquat. Ecol. 7, 17-28.

Pedroli, J. (1977). Relation entre les oiseaux aquatiques et Dreissena polymorpha dans le lac de Neuchâtel. Ornithol. Beob. 74, 86-87.

Petrie, S. A., and Knapton, R. W. (1999). Rapid increase and subsequent decline of zebra and quagga mussels in Long Point Bay, Lake Erie: possible influence of waterfowl predation. J. Great Lakes Res. 25, 772-782. doi: 10.1016/S03801330(99)70776-8

Pollux, B. J., van der Velde, G., and bij de Vaate, A. (2010). A Perspective on Global Spread of Dreissena polymorpha: A Review on Possibilities and Limitations, eds G. van der Velde, S. Rajagopal, and A. bij de Vaate (Leiden, NL: Backhuys Publishers), 45-58.

R Core Team (2017). R: A Language and Environment for Statistical Computing. Vienna: R Foundation for Statistical Computing.

Ram, J. L., Fong, P. P., and Garton, D. W. (1996). Physiological aspects of zebra mussel reproduction: maturation, spawning, and fertilization. Am. Zool. 36, 326-338. doi: 10.1093/icb/36.3.326

Ricciardi, A., Rasmussen, J., and Whoriskey, F. (1995). Predicting the intensity and impact of Dreissena infestation on native unionid bivalves from 
Dreissena field density. Can. J. Fish. Aquat. Sci. 52, 1449-1461. doi: 10.1139/ f95-140

Rodríguez-Rey, M., Consuegra, S., Börger, L., and Garcia de Leaniz, C. (2019). Improving species distribution modelling of freshwater invasive species for management applications. PLoS One 14:e0217896. doi: 10.1371/journal.pone. 0217896

Rolla, M., Consuegra, S., Hall, D. J., and Garcia de Leaniz, C. (2019). Seasonal and spatial variation in growth and abundance of zebra mussel (Dreissena polymorpha) in a recently invaded artificial lake: implications for management. bioRxiv [Preprint]. doi: 10.1101/656371v1

Schloesser, D. W., Nalepa, T. F., and Mackie, G. L. (1996). Zebra mussel infestation of unionid bivalves (Unionidae) in North America. Am. Zool. 36, 300-310. doi: 10.1093/icb/36.3.300

Seaver, R. W., Ferguson, G. W., Gehrmann, W. H., and Misamore, M. J. (2009). Effects of ultraviolet radiation on gametic function during fertilization in zebra mussels (Dreissena polymorpha). J. Shellfish Res. 28, 625-634. doi: 10.2983/035. 028.0327

Spidle, A. P., May, B., and Mills, E. L. (1995). Limits to tolerance of temperature and salinity in the quagga mussel (Dreissena bugensis) and the zebra mussel (Dreissena polymorpha). Can. J. Fish. Aquat. Sci. 52, 2108-2119. doi: 10.1139/ f95-804

Stanczykowska, A. (1977). Ecology of Dreissena polymorpha (Pall.) (Bivalvia) in lakes. Pol. Arch. Hydrobiol. 24, 461-530.

Stanczykowska, A., and Lewandowski, K. (1993). "Thirty years of studies of Dreissena polymorpha ecology in Mazurian Lakes of Northeastern Poland," in Zebra Mussels: Biology, Impacts, and Control, eds T. F. Nalepa, and D. W. Schloesser (Boca Raton, FL: Lewis Publishers), 3-37.

Stoeckel, J. A., Schneider, D. W., Soeken, L. A., Blodgett, K. D., and Sparks, R. E. (1997). Larval dynamics of a riverine metapopulation: implications for zebra mussel recruitment, dispersal, and control in a large-river system. J. North Am. Benth. Soc. 16, 586-601. doi: 10.2307/1468146

Strayer, D. L. (2010). Alien species in fresh waters: ecological effects, interactions with other stressors, and prospects for the future. Freshwat. Biol. 55, 152-174. doi: 10.1111/j.1365-2427.2009.02380.x

Strayer, D. L., D’Antonio, C. M., Essl, F., Fowler, M. S., Geist, J., Hilt, S., et al. (2017). Boom-bust dynamics in biological invasions: towards an improved application of the concept. Ecol. Lett. 20, 1337-1350. doi: 10.1111/ele.12822

Strayer, D. L., and Malcom, H. M. (2006). Long-term demography of a zebra mussel (Dreissena polymorpha) population. Freshwat. Biol. 51, 117-130. doi: 10.1111/j.1365-2427.2005.01482.x

Therriault, T., Orlova, M., Docker, M., MacIsaac, H. J., and Heath, D. D. (2005). Invasion genetics of a freshwater mussel (Dreissena rostriformis bugensis) in eastern Europe: high gene flow and multiple introductions. Heredity 95, 16-23. doi: 10.1038/sj.hdy.6800691

Vaughan, I. P., Newberry, C., Hall, D., Liggett, J., and Ormerod, S. J. (2008). Evaluating large-scale effects of Bacillus thuringiensis var. israelensis on non-biting midges (Chironomidae) in a eutrophic urban lake. Freshwat. Biol. 53, 2117-2128. doi: 10.1111/j.1365-2427.2008.02 043.x

Waller, D. L., and Bartsch, M. R. (2018). Use of carbon dioxide in zebra mussel (Dreissena polymorpha) control and safety to a native freshwater mussel (Fatmucket, Lampsilis siliquoidea). Mgmt. Biol. Invasion. 9, 439-450. doi: 10. 3391/mbi.2018.9.4.07

Walz, N. (1978). The energy balance of the freshwater mussel Dreissena polymorpha Pallas in laboratory experiments and in Lake Constance. II. Reproduction. Arch. Hydrobiol. 55, 106-119.

Watters, A., Gerstenberger, S. L., and Wong, W. H. (2013). Effectiveness of EarthTec ${ }^{\circledR}$ for killing invasive quagga mussels (Dreissena rostriformis bugensis) and preventing their colonization in the Western United States. Biofouling 29, 21-28. doi: 10.1080/08927014.2012.744825

Werner, S., Moertl, M., Bauer, H.-G., and Rothhaupt, K. O. (2005). Strong impact of wintering waterbirds on zebra mussel (Dreissena polymorpha) populations at Lake Constance, Germany. Freshwat. Biol. 50, 1412-1426. doi: 10.1111/j.13652427.2005.01411.x

Whitledge, G. W., Weber, M. M., DeMartini, J., Oldenburg, J., Roberts, D., Link, C., et al. (2015). An evaluation Zequanox ${ }^{\circledR}$ efficacy and application strategies for targeted control of zebra mussels in shallow-water habitats in lakes. Manag. Biol. Invasions 6, 71-82. doi: 10.3391/mbi.2015.6.1.06

Wimbush, J., Frischer, M. E., Zarzynski, J. W., and Nierzwicki-Bauer, S. A. (2009). Eradication of colonizing populations of zebra mussels (Dreissena polymorpha) by early detection and SCUBA removal: Lake George, NY. Aquat. Conserv. 19, 703-713. doi: 10.1002/aqc. 1052

Wisniewski, R. (1974). Distribution and character of shoals of Dreissena polymorpha Pall. Bay Part Goplo Lake. Acta Univ. N. Copernici, Limnol. Pap. $8,73-81$.

Wood, C., Bishop, J., and Yunnie, A. (2015). Comprehensive Reassessment of NNS in Welsh Marinas. Available online at: http://www.nonnativespecies.org/index. cfm?pageid=545 (accessed May 15, 2020).

Wood, S. N. (2001). mgcv: GAMs and generalized ridge regression for R. R News $1,20-25$.

Conflict of Interest: The authors declare that the research was conducted in the absence of any commercial or financial relationships that could be construed as a potential conflict of interest.

Copyright (c) 2020 Rolla, Consuegra, Hall and Garcia de Leaniz. This is an openaccess article distributed under the terms of the Creative Commons Attribution License (CC BY). The use, distribution or reproduction in other forums is permitted, provided the original author(s) and the copyright owner(s) are credited and that the original publication in this journal is cited, in accordance with accepted academic practice. No use, distribution or reproduction is permitted which does not comply with these terms. 